\title{
Primary Biliary Chirrhosis Associated with Scleroderma: Case Report and Review of The Literature
}

Yomna Dannouni $^{1 *}$, Sara Boulajaad ${ }^{1}$, Jihane Rizkou ${ }^{1}$, Adil Ait Errami ${ }^{1}$, Zouhour Samlani ${ }^{1}$, Sofia Oubaha ${ }^{2}$, Khadija Krati $^{1}$

${ }^{1}$ Department of Gastroenterology, Mohamed VI University Hospital, Marrakech, Morocco

${ }^{2}$ Laboratory of Physiology, Cadi Ayyad University Faculty of Medicine and Pharmacy of Marrakech, Morocco

DOI: $10.36347 /$ sjmcr.2020.v08i05.018

| Received: 06.02.2020 | Accepted: 14.02.2020 | Published: 23.05.2020

*Corresponding author: Yomna Dannouni

\section{Abstract}

A 57-year-old housewife with primary biliary cirrhosis associated with scleroderma but without features of the calcinosis-Raynaud's phenomenon-sclerodactyly-telangiectasia syndrome is reported. The mechanisms responsible for the co-occurrence of these diseases are largely unknown. Genetic, epigenetic, environmental, and infectious factors appear to be important for the pathogenesis of the disease, but the hierarchy of events are not well defined. Some case reports suggested that the presence of SSc in PBC patents is associated with a more favorable prognosis of the liver disease, whereas others report an increased mortality in patients with PBC and SSc compared to patients with PBC alone.

Keywords: scleroderma, calcinosis-Raynaud's phenomenon-sclerodactyly-telangiectasia syndrome, PBC and SSc.

Copyright @ 2020: This is an open-access article distributed under the terms of the Creative Commons Attribution license which permits unrestricted use, distribution, and reproduction in any medium for non-commercial use (NonCommercial, or CC-BY-NC) provided the original author and source are credited.

\section{INTRODUCTION}

Scleroderma is a disease of connective tissue often affecting middleaged females which is characterized by leathery, symmetrical skin induration and involvement of muscle, bone, and various internal organs [1]. Primary biliary cirrhosis (PBC) is a chronic cholestatic liver disease characterized by immunemediated chronic nonsuppurative cholangitis that mainly affects interlobular and septal bile ducts, affecting middle-aged women and often accompanied by generalized pruritus, skin hyperpigmentation, and thickening [2]. Many cases of primary biliary cirrhosis occurring in association with scleroderma have been reported and in every instance features of eRST have been evident [3]. We report here the coexistence of primary biliary cirrhosis and scleroderma (Reynolds syndrome) without features of the CRST syndrome in a 57-year--woman.

\section{CASE REPORT}

A 57-year-old housewife without any medical history (no alcohol consumption, smoking, or taking any medication) and there was no family history of note. She was referred to our gastroenterology department. She was admitted to our departement for an Iron deficiency anemia with jaundice. She denied having choluria, acholia and haematemesis, as well as fever, night sweats, myalgia and weight loss. On physical examination, the patient was haemodynamically stable and afebrile. She was a well nourished woman with generalized hyperpigmentation. The skin was tight and thickened over the fingers, forearms, chest, back, and face. Superficial telangiectasias were present over the malar areas of the face. Elbow extension was limited to $160^{\circ}$ and shoulder abduction to $90^{\circ}$. No sclerodactyly, calcinosis or xanthomas were present. Her abdomen was soft, but tender, without guarding or rebound. A large splenomegaly of $17 \mathrm{~cm}$, the liver was not enlarged and no other masses were palpated. On percussion, a shifting dullness was observed, which suggested ascites. Examination revealed no peripheral stigmata of chronic liver disease.

Initial laboratory investigations showed an abnormal liver profile, with hemoglobin $10 \mathrm{~g} / \mathrm{L}$, leukocytes $4370 / \mathrm{L}$ and platelets $175 \times 10^{3} / \mathrm{L}$, aspartate aminotransferase $66 \mathrm{U} / \mathrm{L}$, alanine aminotransferase 73 $\mathrm{U} / \mathrm{L}$, alkaline phosphatase $254 \mathrm{U} / \mathrm{L}$, gamma glutamyltranspeptidase $113 \mathrm{U} / \mathrm{L}$, bilirubin $42 \mu \mathrm{mol} / \mathrm{L}$, albumin $34 \mathrm{~g} / \mathrm{L}$, prothrombin time $96 \%$, total serum protein $65 \mathrm{~g} / \mathrm{l}$. No abnormalities of the esophagus, stomach were demonstrated on an upper gastrointestinal. Colonoscopy revealed rectal varices. An aetiological study was performed, showing a positive antimitochondrial 
antibody (AMA) level and an elevated immunoglobulin IgM. Anti-LKM1, antismooth muscle antibody, antinuclear antibody ANA and anti-SLA were normal. Ultrasonographic examination of abdomen showed showed a normal-sized liver with homogenous structure signs of portal hypertension. Skin and muscle biopsy from the forearm revealed scleroderma in the sclerotic stage and minimal muscle atrophy.

\section{DisCUSSION}

Reynolds syndrome is

an autoimmune disease characterized by the co-occurrence of primary biliary cholangitis (PBC) and limited cutaneous systemic sclerosis (LCSS). This association was first described to co-occur by Milbradt in 1934, and it has been noted historically in several case reports. The patient reported here has primary biliary cirrhosis associated with scleroderma without the features of CRST syndrome. She has no calcinosis, Raynaud's phenomenon, or sclerodactyly, and the telangiectasias present are superficial and not those seen in the CRST syndrome [4]. The random association of primary biliary cirrhosis and sclerosis is highly unlikely since botll disorders are relatively uncommon. The nature of this association remains obscure as the etiology of both diseases is largely unknown. The pathological tissue reaction in both diseases reveals some general similarities. An early inflmatory reaction followed by fibrosis $[5,6]$. This case indicates that the coexistence of primary biliary cirrhosis and scleroderma can occur without features of the CRST syndrome. Fox et al., have described impaired delayed hypersensitivity in patients with primary biliary cirrhosis as measured by their respone to dinitrochlorobenzene and tuberculin skin tests [7, 8]. From the practical point of view, it is important to evaluate liver function in all patients with scleroderma and to investigate all patients with primary biliary cirrhosis for symptoms of connective tissue disorders. These signs are commonly attributed to the multiorgan involvement of the hepatic disease, and in fact are caused by a separate nosological unit.

\section{REFERENCES}

1. Kaplan MM, Gershwin ME. Primary biliary cirrhosis, The New England Journal of Medicine, 2005; 353(12):1261-1273.

2. Hohenester S, Oude-Elferink RPJ, Beuers U. Primary biliary cirrhosis, Seminars in Immunopathology, 2009; 31(3):283-307.

3. Neuberger J. Primary biliary cirrhosis, The Lancet, 1997; 875-879.

4. Winterbauer RH. Multiple telangiectasia, Raynaud's phenomenon: sclerodactyly and subcutaneous calcinosis: A syndrome mimicking hereditary hemorrhagic. telangiectasia. Bull Johns Hopkins Hosp, 1964; 114:361-383.

5. Reynolds TB, Denison EK, Frankl HD, Lieberman FL, Peters RL. Primary biliary cirrhosis with scleroderma, Raynaud's phenomenon and telangiectasia: New syndrome. The American journal of medicine. 1971 Mar 1;50(3):302-12.

6. Murray-Lyon IM, Thompson RP, Ansell ID, Williams R. Scleroderma and primary biliary cirrhosis. Br Med J. 1970 Aug 1;3(5717):258-9.

7. Fox RA, Scheuer PJ, James DG, Sharma O, Sherlock S. Impaired delayed hypersensitivity in primary biliary cirrhosis. The Lancet. 1969 May 10;293(7602):959-62.

8. Fox RA, James DG, Scheuer PJ, Sharma O, Sherlock S. Impaired lymphocyte response in primary biliary cirrhosis. Proc R Soc Med, 1970; 63:357-358. 